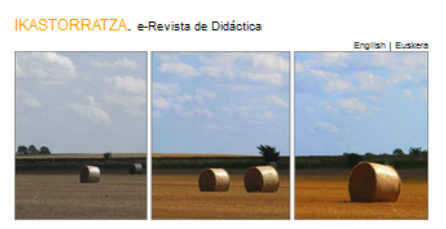

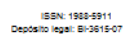

Inicio, Sobre nosotros, Publicacionesl, Participe

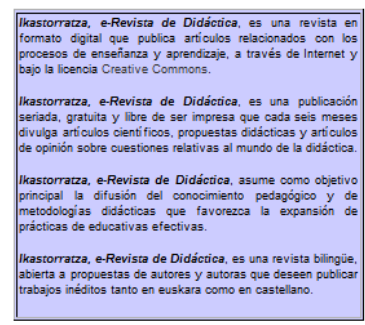

\section{IKASTORRATZA. Didaktikarako e-aldizkaria}

IKASTORRATZA. e-journal on Didactics

ISSN: 1988-5911 (Online) Journal homepage: http://www.ehu.eus/ikastorratza/

Theatre as a Communicative Strategy for Teaching English as a Foreign Language to Primary Education Undergraduates: A Pedagogical Experience

\author{
IKASTORRATZA. e-Revista de \\ Didáctica
}

Betlem Soler Pardo

Betlem.Soler@uv.es

To cite this article:

Soler, B. (2020). Theatre as a Communicative Strategy for Teaching English as a Foreign Language to Primary Education Undergraduates: A Pedagogical Experience. IKASTORRATZA. e-Revista de Didáctica, 25, 133-150. DOI: https://10.37261/25_alea/5

To link to this article:

https://doi.org/10.37261/25_alea/5

Published online: 31 october 2020 


\title{
Theatre as a Communicative Strategy for Teaching English as a Foreign Language to Primary Education Undergraduates: A Pedagogical Experience
}

\author{
Betlem Soler Pardo \\ Didáctica de la Lengua y la Literatura. \\ Universitat de València \\ Betlem.Soler@uv.es
}

\begin{abstract}
As language teachers we are constantly trying to establish a suitable atmosphere in which communication skills can be fully developed through activities or exercises which involve a stimulus, as a language is learnt more easily when the elements used to teach are more appealing. Theatre can perform this role as it is an educational tool that has been explored for the instructions of languages since the emergence of the Communicative Approach.

The purpose of this article is twofold: firstly, to examine the effectiveness of theatre in general with reference to the numerous arguments in favour of using this didactic tool in the classroom. Secondly, to draw attention to the benefits and challenges of using theatre to teach a foreign language at university level by presenting the performance of eight plays based on popular tales in the classroom through a series of practical activities using the task-based learning methodology.
\end{abstract}

Kewords: English as a Foreign Language, theatre as a didactic tool in the classroom, task-based learning, undergraduate students 


\section{El teatro como estrategia comunicativa para enseñar ILE con estudiantes del Grado de Primaria: una experiencia docente}

\section{Resumen}

Como profesores de lenguas estamos constantemente tratando de establecer un ambiente apropiado para que las cuatro destrezas se desarrollen plenamente a través de actividades o ejercicios que implican un estímulo, ya que un idioma extranjero se aprende más fácilmente cuando los elementos utilizados para enseñar son más atractivos. El teatro puede desempeñar este papel, ya que es un género educativo que se ha explorado para la enseñanza de lenguas desde el desarrollo del Enfoque Comunicativo.

El propósito de este artículo, por tanto, es en primer lugar, examinar la efectividad del teatro en general con referencia a los numerosos argumentos a favor de la utilización de esta herramienta didáctica en el aula. En segundo lugar, resaltar los beneficios y desafíos de utilizar técnicas de teatro para enseñar una lengua extranjera a nivel universitario presentando la implementación de ocho obras de teatro basadas en cuentos populares en el aula a través de una serie de actividades prácticas utilizando la metodología del aprendizaje por tareas.

Palabras clave: inglés como lengua extranjera, teatro como herramienta didáctica en el aula, aprendizaje por tareas, alumnos universitarios 


\section{Introduction}

As language teachers we are always looking for new ways to improve our classes. We try to establish a suitable atmosphere in which communication skills are fully developed through activities or exercises which involve a stimulus, since a language is learnt more easily when the elements used to teach are more appealing. Theatre ${ }^{1}$ can perform this role as it is an educational tool that has been explored for the instructions of languages since the emergence of the Communicative Approach ${ }^{2}$. I believe, then, that its practise in the classroom could help students learn a foreign language as active learning and teaching procedures are combined.

The use of theatre in the classroom was introduced in schools to develop different capacities: (1) acting skills; (2) improvisation; (3) natural expressivity; (4) refinement of the language; or (5) confidence increase since "it is fun and entertaining and can therefore provide motivation to learn. It can provide varied opportunities for different uses of language and because it engages feelings it can provide a rich experience of language for the participants” (Fleming, 2006, p.1). Besides, theatre offers myriad possibilities for teaching and/or learning since it is a method that can be adapted in the classroom depending on students’ needs. As such, its potential value ought not to be underestimated in the English classroom. In addition, whilst traditional methods are teacher-centred, theatre can be learner-centred as it requires active cooperation; hence, roles automatically change and pupils can develop their skills in a more autonomous and active manner, so that they can "explore and play with reality” (Motos, 2017, p.345):

theatrical performances are emotional, vivid, and based on experience. Theatrical practice proposes a physical and, above all, psychological space, in which to inquire, explore and play with reality. Young people can re-evaluate and relive reality from their own personal attitudes and from that of the characters in the roles they play ${ }^{3}$ (p.345).

Furthermore, the fact that language is applied in real situations makes the process meaningful as stated by Ausubel in 1963. This scholar carried out research into meaningful learning based on the premise that a student learns better the concepts that s/he perceives as useful or important for his or

\footnotetext{
1 Despite the fact that Fleming (2006) distinguishes between theatre and drama, the former referring to works performed on stage and the latter to improvised works, in this paper, I shall employ the term "theatre" to refer to both.

2 The Communicative Approach or Communicative Language Teaching (CLT) is a language teaching method in which emphasis is given to interaction as a means and as the final objective in the learning process. Harmer (2003, p.70) suggests that the communicative method can be used as an umbrella term that encompasses learning and seeks to improve students' ability to communicate.
}

3 My translation. 
her development, and stores these concepts in the permanent memory; if, on the contrary, s/he does not consider it relevant, the individual will store them in the short-term memory. Theatre can perform this role because the new information can be integrated into the old knowledge structure and students use the language in a real context.

Nevertheless, regardless of its great potential, there are some pre-(conditions) to be taken into account before deciding to use theatre in the classroom. Theatre -as an instructional tool- implies a series of trials, as Fleming (2006, p. 3) highlights, not only for the student but also for the instructor who needs to be willing to accept that several difficulties may arise: (1) students' potential embarrassment when acting in front of a class; (2) problems of discipline due to excitement; and (3) fluency difficulties if the student has a low command of the foreign language, which can impede the communication of the play. It is crucial that teachers take these aspects into account before being immersed into this practice so as to be prepared to address the obstacles, but this should not discourage educators from using theatre to teach a foreign language ${ }^{4}$.

Theatre's value resides in the fact that it permits the recreation of numerous situations for different language uses (e.g. learning a foreign language) (Fleming, 2006). Traditionally, most publications on theatre as a language teaching tool are addressed to primary or secondary education, and not many are focused on university level (Giebert, 2014, p.139). In this study, I shall attempt to focus on undergraduate students who are aiming to become EFL primary school teachers in Spain. Therefore, the purpose of this article is twofold: firstly, to examine the effectiveness of theatre in general with reference to the numerous arguments in favour of using this didactic tool in the classroom. Secondly, to draw attention to the benefits and challenges of using theatre as a means to teach a foreign language at university level by presenting the implementation of eight plays based on popular tales in the classroom through a series of practical activities using task-based learning to frame the activity.

\section{Theoretical Framework}

\subsection{A Brief Review on Theatre}

Theatre has always been present in the classroom, as stated by Maley and Duff (2005) or Fleming (2006), but became more significant during the 1970s with the advent of the Communicative Paradigm. Furthermore, Maley and Duff (2005, p. 158-159) and (Fleming, 2006, p. 3) stated that

4 While doing the exercise, my students experience one or more or the difficulties here posed, but this did not prevent them from carrying on with the practice. 
theatrical practices had been always present in education in the form of varied activities, games or simulations.

Bolton (1984) and Heathcote (1984) were the first scholars to highlight the importance of the presence of theatre in the first language classroom, and encouraged teachers to incorporate it in their lessons. Following Bolton's and Heathcote initiative, second and foreign language practitioners started to develop new strategies to integrate this potential tool into their foreign language (FL) classes as they viewed that theatre could effectively tackle the four basic skills: reading, speaking, writing and listening (Dodson, 2000, p. 139; Dundar, 2013, p. 1425; Aldavero, 2008, p. 43). As stated by Zyoud (2010, p. 1):

[it] is a powerful language teaching tool that involves all of the students interactively all of the class period (...) Teaching English as a foreign language inevitably involves a balance between receptive and productive skills; here drama can effectively deal with this requirement (...). [it] also fosters and maintains students' motivation, by providing an atmosphere which is full of fun and entertainment.

In the case of Spain, the use of theatre in the classroom was included in the Spanish curriculum in 1970 with La Ley General de Educación (LGE) 14/1970, de 6 de Agosto [the General Education Law], but it was not until the end of the 1980s and during the whole 1990s when theatre became more widespread in educational practice. Nevertheless, besides having been part of the Spanish curriculum until the implementation of La Ley Orgánica (LOE) 2/2006, de 3 de mayo, de Educación [the Organic Law of Education], theatre had not been a very popular practice in the classroom in Spain probably due to the long tradition of textual hegemony privileging philology over performance (Wheeler, 2012, p. 54).

However, the many possibilities that theatre has for the language classroom should not be disregarded. As Horace observed: -Prodesse et delectare [to instruct and to delight]- as well as a privileged form of entertainment, theatre can also function in some, but by no means all cases, as a preferred pedagogical tool due to its literary value. I suggest that instructing and delighting be linked together so that the teacher can focus on both concepts in the classroom: on the one hand, theatre can provide academic benefits as well as keeping students entertained as participants can become motivated and excited about dressing-up, acting and performing in front of an audience. Thereby, both verbal and non-verbal signals can be explored jointly.

Fleming (2006), on the other hand, discussed the importance of theatrical techniques and language teaching in the classroom to promote cultural awareness (p. 5). Fleming (2006) also depictures the 
differences between teaching drama and theatre as established in the 1980s. The main dissimilarity will rely on the fact that drama, according to Fleming (2006), refers to shorter plays and requires more improvisation, and theatre is seen as a more literary product that requires more rehearsing in order to achieve a more refined product.

With this revision on theatre, a teacher can be informed on the practicalities and rejections of using it in the classroom. For instance, theatre could be seen as a static practice, and instructors should take it into account before planning their tasks. In addition, when used in the foreign language class, the narrative or script should not be too complicated since this is likely to distract from the primary purpose of the activity (p. 6).

\subsection{Why theatre? Benefits and Challenges of using theatre in the classroom}

It has been proved that the most efficient way to learn a language is to do so via a real context, with everyday situations in which the learner can feel identified in order to attain meaningful learning (Ausubel, 1963). Theatre could provide us with this scenario since it does not only imply performing a play but it engages students actively in the whole process by using the language in context which, as suggested by Savignon (1991, p. 270), will mean that their communicative competence will be enhanced. Furthermore, theatre "[...] presents student language teachers with a very different pedagogical model to that which is the norm within the Modern Language (ML) classroom” (Hulse \& Owens, 2019, p. 18). Through the various series of tasks, students will be able to create a fictional world in which they could use the language in settings, something that will seldom occur in the habitual development of the class.

Philips (2003, p. 6) also concurs that theatre is motivating and entertaining, and it could also be added that it opens the door to the imagination. Hence, there are many advantages we could think of as regards its use as a pedagogical tool to learn a foreign language. These include but are not limited to the following ideas outlined by Wessels (1987, p.10) and Philips (2003, p. 7): the learner gains fluency; theatre develops improvisation; promotes motivation and encouragement; improves pronunciation and intonation; increases students' self-confidence and self-esteem; encourages social competence since it is a collaborative task; allows for the acquisition of new vocabulary; facilitates the acquisition of new grammatical structures; students explores different language registers; and also his/her inhibitions decrease (Wessels, 1987, p. 10; Philips, 2003, p. 7). To this, Lavery (2009, unpaginated) adds: theatre improves reading, writing, listening and speaking skills; inspires creativity; students experiment with body language; and learners help with the writing or rewriting of a play. 
Broadly speaking, participants are learning because they are using the language in context through a series of communicative exercises that result in the enhancements of the abilities presented above. Wessels (1987, p. 53-54) also explains that theatre can help students learn "by making the learning of the new language an enjoyable experience; by setting realistic targets for the students to aim for; by the creative 'slowing down' of real experience; by linking the language-learning experience with the students' own experience of life” (p. 53). She adds that a theatre play can prompt the necessity to learn the language because of the creation of situations whereby an immediate solution is required, and also by delegating more responsibility onto the learner instead of the teacher (p. 54). The role of the teacher will be more as a facilitator or a supporter whilst the student will take charge of his/her learning process, acting as potential teachers themselves, which will give them the opportunity for independent thinking by expressing their own thoughts and by putting them into practice.

On the other hand, the use of theatre in the classroom has also been dismissed by some teachers who are reluctant to use this practice (Royka, 2002) because they believe: (1) there is not enough time in the curriculum to carry out this task; (2) there are limited resources; (3) they do not know how to focus the activity; (4) they feel they are being unprofessional and rather follow the textbook to teach; (5) it is ludic and, thus, cannot be considered instructive; and, finally, (6) they consider that the advantages are not sufficient to justify the risk. Nevertheless, these impediments often arise when working with adults since the classroom practices of primary school teachers ensure that they are generally more willing to explore through games, drama activities, and so on since children are known to discover new things through playing, and theatre will fit in their learning development unlike some adults.

Fleming (2006, p. 3) suggested a series of different exercises which could take place in the class. Among the different exercises that could be considered, the following stand out: (1) Warm-ups and games in which they can work in pairs or in small groups; (2) Improvised role-plays which could be seen as small performances in which students can get in pairs to act out extempore; (3) Less improvised situations in which they can write short dialogues; (4) Drama plays which can be short (it can last a few minutes) or long (it can take several months); and (5) Silent activities, which could help to calm those participants who are more anxious about these kind of activities (Gregersen, 2007, p. 62-63).

In sum, teachers of a foreign language had found the inclusion of theatre practices in the classroom a beneficial pedagogical tool that can provide students with dynamic situations in which they will be able to speak freely in a real context setting. As Colangelo and Ryan (2004, p. 375-376) describe, it is through this kind of setup when learners can "truly begin to explore sociopragmatic uses of verbal 
as well as nonverbal language”. Based on the aforementioned arguments advanced by multiple scholars as regards the use of theatre in the classroom with young learners, I decided to implement it as a methodological tool to learn a FL at university level given what I perceive to be a gap in the existing scholarship: few studies have analysed the efficiency of this potential tool to learn a FL with adult learners (Chin Su, 2014; Giebert, 2014). Additionally, I shall use task-based learning to frame the activity. Thus, in the following sections, I shall describe the didactic experience of using theatre in the classroom with university students, who will represent eight short plays in front of their peers (see 3.2).

\subsection{Task-Based Learning}

Task-Bask Learning or TBL focuses on the development of communicative competence through a series of activities or tasks. It constitutes a useful methodology that can guide the teacher to design a lesson that can be easily followed by the students in the classroom. It involves consideration of three different phases proposed by various scholars such as Willis, 1996; Skehan, 1998; and Ellis, 2006. These authors propose having three phases in the activities: pre-task, during the task and post-task. During the pre-task, students are asked to carry out activities previous to the start of the exercise itself as, for example "framing of the activity" (Ellis, 2006, p. 80) such as establishing the groups, choosing the drama play, altering the script if needed, and “planning time and doing a similar-task” (p. 80). This usually involves a whole-class exercise and sets the context for the activity. For the second phase or during-task phase, students focus on the activity or main task itself. It is the longest of all phases and it can be considered the backbone of all three activities. During this phase, the teacher also acts as a guide or facilitator and provides the students with feedback. Learners, on the other hand, work together in order to construct the plays in an autonomous way. Finally, for the post-task phase, students are able to consolidate on the reviewed concepts and at the same time reflect on what they have learned through a series of different exercises proposed by the teacher, which also includes a review of possible errors committed by the learners during all three phases. Throughout this phase, students move from focusing on meaning to focusing on form, which involves reviewing some grammar points. The determination of the methodology, thus, consists of "creat[ing] opportunities for language learning and skill-development through collaborative knowledge-building” (Ellis, 2006, p. 97).

Hence, by using TBL, a natural environment in which students can play an active role in the classroom and can carry out a series of meaningful tasks is intended since Task-based language pedagogy attracts students' attention; makes them work together as part of a team; puts emphasis on meaning and forces participants into producing extended utterances -both written and speaking- in 
authentic situations. In this way, thus, students learn by doing and the activity is student-centred instead of the traditional teacher-centred approach as previously stated.

\section{Methodology}

In order to carry out my project, the TBL was applied through the myriad activities students have to complete prior to the performance since in TBL the focus is on communicating meaning, which is a paramount component of this exercise. Therefore, as mentioned in the introduction, the activities students have to accomplish in order to complete these eight plays are in accordance with the TaskBased Learning (TBL) model. The performance of a theatre play can be a task based on students' specific needs (e.g. based on improvements on their pronunciation, grammar or lexicon), which can provide interaction in the foreign language, and can also establish connections with real situations as articulated by Nunan (2004).

The participants were a group of 51 students (50 Spanish and 1 German) in their third year who were studying to become primary school teachers specialising in English at the Faculty of Education (University of Valencia); the project took place during the academic year 2018-2019 and lasted three months. As suggested by Fleming (2006) students' degree of fluency was considered before undertaking a project of these characteristics. In our case, students had a good command of the language and their degree of fluency in English was appropriate to carry out the task ${ }^{5}$. Table 1 below summarises the background of my students:

\begin{tabular}{|l|l|}
\hline \multicolumn{2}{|c|}{ STUDENTS' PROFILE } \\
\hline Name of course & English Language I \\
\hline Background & $\begin{array}{l}\text { Faculty of Education } \\
\text { (UV) }\end{array}$ \\
\hline Number of participants & 51 students \\
\hline Level of English according to the CEFR & B2/B2+ \\
\hline Selected plays & 8 \\
\hline $\begin{array}{l}\text { Number of students whose main subject is } \\
\text { English }\end{array}$ & 51 \\
\hline Months of preparation & 3 months \\
\hline
\end{tabular}

Table 1. "Participants' Background'

\footnotetext{
${ }^{5}$ Before taking this subject, students have been asked to provide evidence of at least a B2 level according to the CEFR (Council of Europe, 2001).
} 
Hence, after reviewing the literature on the long tradition of theatre and examining the many possibilities that this could offer, I decided to include theatre as part of the syllabus for the subject “English Language I” where learners’ level oscillated between B2 and B2+. Students were asked to carry out a project based on a theatre play -worth $25 \%$ of their final mark- which they will have to modify and deliver in front of the class.

To begin with, the list of B2 competences provided in the Common European Framework of Reference (CEFR) to base the project on was consulted, and the strategies the students should develop focusing on the value of the various uses of language: ludic and aesthetic (Council of Europe 2001, p. 55-56) were also specified:

\begin{tabular}{|c|c|}
\hline Ludic & Aesthetic \\
\hline $\begin{array}{l}\text { Social language games: } \\
\text { - oral (story with mistakes; how, when, } \\
\text { where, etc.); } \\
\text { • written (consequences, hangman, etc.); } \\
\text { - audio-visual (picture lotto, snap, etc.); } \\
\text { - board and card games (Scrabble, Lexicon, } \\
\text { Diplomacy, etc.); } \\
\text { - charades, miming, etc. }\end{array}$ & $\begin{array}{l}\text { - singing (nursery rhymes, folk songs, pop } \\
\text { songs, etc.) } \\
\text { - retelling and rewriting stories, etc. } \\
\text { - listening to, reading, writing and speaking } \\
\text { imaginative texts (stories, rhymes, etc.) } \\
\text { including audio-visual texts, cartoons, }\end{array}$ \\
\hline $\begin{array}{l}\text { Individual activities: } \\
\text { • puzzles (crossword, rebus, anagram, etc.); } \\
\text { - media games (TV and radio: chiffres et } \\
\text { lettres, Catchword, etc.). }\end{array}$ & $\begin{array}{l}\text { - performing scripted or unscripted plays, } \\
\text { etc. } \\
\text { - the production, reception and performance } \\
\text { of literary texts, e.g.: reading and writing }\end{array}$ \\
\hline $\begin{array}{l}\text { Verbal joking (punning, etc.) e.g. in: } \\
\text { • advertisements e.g. (for a car) 'Make your } \\
\text { money go a long way'; } \\
\text { • newspaper headlines e.g. 'Feminism or } \\
\text { bust!'; } \\
\text { • graffiti e.g. 'Grammar rules - O.K.?' }\end{array}$ & $\begin{array}{l}\text { texts (short stories, novels, poetry, etc.) and } \\
\text { performing and watching/listening to } \\
\text { recitals, drama, opera, etc). }\end{array}$ \\
\hline
\end{tabular}

Table 2. "Ludic and Aesthetic Uses of Languages"

\subsection{Selecting and Implementing a Theatre Play in the Classroom: A Pedagogical Experience}

The main goal in creating this project was to encourage students to learn English through real-time use by creating a setting in which language situations that will not usually happen in the classroom could take place. In this manner, as stated before, language is applied in real situations and makes the process meaningful (Ausubel, 1963). Therefore, the learner will have to go through a number of phases before the final product was completed (the pre-task phase, the during-task phase, and the post-task phase following Ellis’ (2003, 2006) model). 


\subsection{Procedure}

In order to get started, first of all, students were given simple instructions to gain a general overview of what was expected from them as shown below in the instructions:

\section{Read, rewrite, rehearse, setup, dress-up... perform!}

Get in groups of 5 to 10 participants and select a short play from the list provided by the teacher which you will learn to deliver in class; you are free to make any modifications to it. Alternatively, you can create your own original play. Remember that each individual has to interact in the performance, which should not exceed 20 minutes.

Thus, secondly, the teacher showed them a variety of relevant plays in English that thought could meet their expectations, and told them that the play had to be performed in front of an audience comprising all the members of the class. The teacher oriented them, but learners had the final say. Secondly, they were told that the performance should not exceed 20 minutes and the number of participants had to range from 5 up to10 characters per play. Thirdly, students selected their script and informed the teacher about their choice. Students were encouraged to make modifications in the play chosen, or to create an original play themselves in which they could develop ideas of their own and, thus, improve their writing skills and enhance their critical thinking. They also had to carefully choose the music and the atrezzo for their chosen works, although they were told that the main focus had to be on the academic work. In addition, the story had to be suitable for performance in front of primary school students since one of the purposes is that they use the play as a didactic tool for their lessons when they had a class of their own. The table below condenses the guidelines:

Step 1: Several websites and books with theatre plays were passed in the classroom. Students were asked whether they were familiar with the selected plays and whether they have read them.

Step 2: Students decided on the members of the group (5 minimum and 10 maximum)

Step 3: Selection of the play/creation of an original piece that has to last 15-20 minutes.

Step 4: Selection of music and atrezzo.

Table 3. “5 Steps to create a theatre play”

Next, I shall describe the different activities, based on TBL, students have to undertake in order to complete the tasks previous to the performance of the play:

a) Pre-task

Once ascertained that the working structure was clear, students started working on their project. This first two sessions were carried out in the classroom under my supervision and guidance. During this pre-task sessions, students got into groups and selected the play they wanted to perform in class 
and altered it when necessary. Once the script was finished, they gave it to me to correct the possible mistakes, I returned it to them with feedback. Then, students practised the performance task together, and helped each other with it. They started to rehearse. Next, they chose the music, and the atrezzo.

In addition, two more hours during the term were dedicated to answering any questions in class relating to the play, but after those sessions finished, students had to carry on preparing their work outside the classroom. In this manner, the pre-task had hybrid sessions (in class and outside class), and we could continue with regular classes without leaving questions raised by the students related to the theatre play. Additionally, the teacher was always available to deal with matters relating to the theatrical task during her office hours or via e-mail.

b) The task phase

First of all, before we started, and as mentioned in the introduction, I took the challenges mentioned by Fleming (2006, p.3) into account in order to be prepared to face such problems. Overall, students responded well and could overcome those challenges with the help of the teacher and their peers.

Students were required to perform in front of the class under time pressure since a limit of 15-20 minutes to carry out the performance was set. Learners were not permitted to keep text or notes during the performance. This increased the complexity of the task, but it also encouraged them to work harder. During this phase, students performed in front of the class while their peers and teacher observed them and made a few comments/observations about a series of aspects related to grammar, pronunciation, intonation, vocabulary, creativity, acting, and atrezzo by employing an assessment rubric (see Annex A).

c) The post-task phase

This final phase consisted of giving feedback and asking the performers questions taking the aforementioned matters (e.g. grammar, pronunciation, etc.) into account. Students could ask questions to each member of the group regarding any particular topic that concerned them. Participants could also see their mistakes recorded. Permission to video-record the performances for didactic purposes was necessary since, in this manner, learners were able to observe themselves and learn from their errors. In addition, students were given a questionnaire previously elaborated by the teacher which contained open inquiries with reference to the whole experience of making a theatre project in which they could highlight positive and negative aspects of carrying out a play in class (see Annex B). 


\subsection{Performing phase}

After three months of preparation and cooperative work, students delivered their scripts in front of their classmates. They were organized in eight groups which performed parodies and/or adaptations of plays based on popular tales: Hansel and Gretel; Cinderella; Little Red Riding Hood; The Princess and the Pea; Alice in Wonderland; Goldilocks and The Three Bears; Sleeping Beauty; and The Three Little Pigs respectively. Although some groups did alter the play substantially (e.g. The Princess and the Pea; Sleeping Beauty; Cinderella, and Little Red Riding Hood) none decided to create a script of their own; nevertheless, the modifications were significant and some plays could be considered as independent entities from the original script. Performances took place during four days and all learners attended their classmates' representations willing to help them by giving them feedback or supporting them in any technical or dress-up last-minute matters that may have spontaneously arisen.

\section{Assessment of my Didactic Experience}

The data collection tools employed to assess the didactic experience relied on the use of an assessment rubric (annex A), direct observation and open questions in the form of a questionnaire (annex B).

In order to assess students' work, I designed an analytic rubric (see Annex A), which contained eight components based on the criteria I wanted to base my assessment on (e.g. voice and pronunciation, grammar and vocabulary etc.). Moreover, under each criterion I introduced a scale to judge the quality (from 1-4). The designed rubric, thus, has provided my students with clear and directed feedback that will help them improve their learning at the same time that it will orient me to give them grades for the work they have done.

The next assessment instrument was direct observation. Informal assessment through direct observation was used by monitoring the students and by taking notes about their performances and progress in class. Watching the students in the classroom and making use of this observational study method, allowed me to collect evaluative information to add to the results of the rubric and award them a final grade.

Finally, a series of questions were elaborated in the form of a questionnaire (see Annex B) that was passed on to the students at the end of all phases. The questionnaire contained 6 open questions with reference to the whole experience of making a theatre project in which they could highlight positive and negative aspects of carrying out a play in class; questions were based on the degree of engagement 
and usefulness of the practice. Once students handed in their responses, each item was analysed individually; the results obtained, gave us enough information to link it with the aims established.

Regarding the results, after having done all the tasks and based on the information gather from the assessment rubric, I was able to determine the following outcomes:

1) As they were told that the duration of the performance should not exceed 20 minutes, students were able to condense their scripts in a coherent and concise manner, being able to retain the most relevant details and exclude the insignificant ones.

2) This resulted in well-structured and creative descriptions that held the audience's attention.

3) Students employed relevant and often new lexis throughout the representation, which implied that their vocabulary had expanded.

4) The use of different grammar constructions was also patent in the texts they delivered and the degree of fluency increased. They felt more confident at a speaking level as they normally are in regular lessons probably because they felt secure in the class context.

5) Students' feedback to other participants was meaningful and constructive and they all took notes of what their classmates were suggesting to use it as improvement measures.

6) Finally, as a result of the above-mentioned aspects, language learning motivation had increased probably, as stated by Giebert (2014, p. 143), due to "a more (physically) active learning including the learner's whole person, an experience of collaboration, a sense of achievement and taking joy in a creative approach”.

Overall, students provided positive feedback about the way the project developed and how they benefited from it. As confirmed by Hulse and Owens (2019, p. 19), "learners respond very positively to opportunities to co-create the dramatic narratives that bring these worlds into being”.

Hence, based on students' responses, the following can be stated: one student mentioned that the activity was helpful because she had learnt new lexis, had been able to interact with other peers, and had experimented new experiences too. She added that, additionally, it was also "funny": "You interact with more students and learn new vocabulary. You also have to do new things that make you go beyond yourself, so there are new experiences, and of course it is funny”. ${ }^{6}$ Another student mentioned that it was "funny and exiting" and that she will put it into practice in her class with her future primary school's students. One participant mentioned the fact that it was the first time that she had studied a theatre play in class in English; however, she mentioned that she had done three more in the past probably in Spanish or Catalan, her mother tongues: "I had done three plays before, but

\footnotetext{
${ }^{6}$ I cited directly from their feedback in English and, as such, there are some grammatical mistakes.
} 
none of them in English". The answer of one of the participants to the question: "Do you consider your confidence in speaking in class has grown after carrying out the performance with your classmates?” was also positive, although he claims not to have been specifically concerned with this matter, he added that it was positive: “I don’t think that has make a very big change because I was already confident. But I think it is always good and makes a little difference”.

Another learner mentioned the fact that they had to write or re-write the script of the play was useful to learn new words in context and added that they learnt a lot through the process: "I think it was useful because we had to write the script of the play so we had to look for the appropriated words for every moment and with that we learnt a lot”.

All of them responded "yes" to the question of whether they would use this tool in class for the future: "I would do it because I think it is a funny activity and they can learn a lot from it". To which another participant added: "Yes, I will put it into practice".

Students also highlighted the challenges of working in groups, and how other peers had experienced problems due to the lack of commitment: "I enjoyed working with my group but I heard that other groups had problems because the members of the group were not involved in the same way and that is something that always happens”.

When students where asked about their favourite part they gave different opinions: "I enjoyed everything but my favourite part was writing the play because writing jokes in paper and after check if makes people laugh or not is something that I find really thrilling”. And another participant said: "The most enjoyable for me was decorating everything and dressing us up, and of course, the performance”.

In general, the feedback received from the students, as shown above, indicated that participants not only enjoyed bringing out a play in English but they also emphasized: (1) the fact that they have learnt from each other; (2) that they have been aware of their linguistic progress while rehearsing for the play; and, as teachers-to-be, (3) they are now conscious of the many possibilities that this resource can offer for primary school students too. 


\section{Conclusions}

The didactic proposal presented here consisted of creating a play within a task-based framework in which students read, (re)wrote, spoke, reasoned, interacted, and worked together with their peers in a dynamic group project with the support of a written script and the guidance of their teacher. This implied that students had to develop their abilities in a semi-independent ${ }^{7}$ way using theatre as a methodology. This meant that the process would be learner-centred, as established at the beginning. Notwithstanding, in line with Fleming (2006, p. 6), it is important to highlight the fact that theatre has been tackled in this study as a complement to other approaches and not as a substitute of them.

Throughout this article, we have been able to ascertain that theatre could be a means to learn a foreign language since it can integrate both verbal (pronunciation, vocabulary, grammar, listening, fluency) on the one hand, and non-verbal aspects (cultural aspects, group work abilities and selfconfidence). It has also proven that theatre can provide motivation to learn, can enhance the teaching process and that it can strongly engage adult learners and reinforce their confidence, as stated by Fleming (2006, p.1), at the time it opens forms of communications with their classmates. Moreover, as stated by Wessels (1987) and Philips (2003), and as deduced from the questionnaires, the direct observation and from the rubric employed to assess learners, our students gained fluency; developed improvisation; improved their pronunciation and intonation; acquired new vocabulary and new grammatical structures; and their self-esteem increased at the time their inhibition decreased.

As a teacher of a foreign language, I keep seeking out new ways to teach English in the classroom in which constrains such as time and space are constantly present. I came across theatre after reading about the long tradition of theatre to teach both first and second languages in the United Kingdom and how this tool had become a resourceful strategy for British teachers, and, thus, decided to examine it more deeply and apply it in my classes in Spain; the results have shown that it was worth the effort. In addition, this experience has encouraged me (and hopefully others) to consider exploring the efficacy of theatre as a didactic experience in the undergraduates' classroom to learn a foreign language in the future. Furthermore, after witnessing the benefits of using theatre in my classroom, I am able to state that the use of this tool to teach a FL should not be undervalued or displaced to an end-of-class activity but should rather be undertaken as a serious tactic that can provide us with a myriad of resources. On this grounds, I would like to pose the following question: Theatre in the University classroom? Why not...

\footnotetext{
${ }^{7}$ I use the term "semi-independent" here since, although students work autonomously, they were guided and monitored by the teacher constantly.
} 


\section{Bibliography}

Aldavero, V. (2008). Drama in the development of oral spontaneous communication. Encuentro 17, 40-43. Retrieved from www.encuentrojournal. Org/textos/Alonso.pdf.

Ausubel, D. (1963). The Psychology of Meaningful Verbal Learning. New York: Grune \& Stratton.

Bolton, G. (1984). Drama as education: An argument for placing drama at the centre of the curriculum. Essex, England: Longman.

Carson, L. (2012). The role of drama in task-based learning: Agency, identity and autonomy. Scenario, 6(2), 47-60. Retrieved from http://research.ucc.ie/scenario/2012/02/Carson/06/en.

Chin Su, S. (2014). The Advantages, the Disadvantages, and the Obstacles from Students' Perspectives on a Short-term University Drama Play as a Service Participation. International Journal of Humanities and Cultural Studies (IJHCS), 1(3), 1-20.

Colangelo L. M. \& Ryan-Scheutz, C. (2004). Full-Scale Theater Production and Foreign Language Learning. Foreign Language Annals, 37(3), 374-385.

Council of Europe (2001). Common European Framework of Reference for Languages: Learning, Teaching, Assessment, Cambridge, New York: Cambridge University Press.

Dodson, S. (2000). Learning languages through drama. Texas Foreign Language Conference: Texas, 2-5.

Dundar, S. (2013). Nine drama activities for foreign language classrooms:Benefits and challenges. Procedia - Social and Behavioral Sciences, 70, 1424-1431.

Ellis, R. (2003). Task-Based Language Learning and Teaching. Oxford: Oxford University Press.

Ellis, R. (2006). The Methodology of Task-Based Teaching. The Asian EFL Journal Quarterly, 8(3), $19-45$.

Fleming, M. (2006). Drama and language teaching: the relevance of Wittgenstein's concept of language games. Humanising Language Teaching, 8(4),97-110. Retrieved from http://www.hltmag.co.uk/jul06/mart01.htm.

Giebert, S. (2014). Drama and theatre in teaching foreign languages for professional purposes. Langues de spécialité et professionnalisation, 23(1), 138-150. https://doi.org/10.4000/apliut.4215

Gregersen, T.S. (2007). Language learning beyond words: Incorporating body language into classroom activities. Reflections on English Language Teaching, 6(1),51-64.

Harmer, J. (2003). Popular culture, methods and context. ELT Journal, 57, 288-294. https://doi10.1093/elt/57.3.288.

Heathcote, D. (1984). Collected writings on education and drama. Illinois: Northwestern University Press. 
Hulse, B., and Owens, A. (2019). Process drama as a tool for teaching modern languages: supporting the development of creativity and innovation in early professional practice. Innovation in Language and Teaching, 13(1). https://doi.org/10.1080/17501229.2017.1281928

Lavery, C. (2009). Using plays in the language class. British Council. Retrieved from https://www.teachingenglish.org.uk/article/using-plays-language-class

Ley 14/1970, de 4 de agosto, General de Educación y Financiamiento de la Reforma Educativa,

BOE de 6 de agosto de 1970.

Ley Orgánica 2/2006, de 3 de mayo, de Educación, BOE de 4 de mayo de 2006.

Maley, A. and Duff, A. (2005). Drama Techniques: A resource book of communication activities for language teachers. Cambridge: Cambridge University Press.

Motos Teruel, T. (2017). Diseño y validación de la batería “El teatro y yo”: evaluación del impacto de la experiencia teatral en los jóvenes. Crear Mundos, 15, 344-353.

Nunan, D. (2004). Task-Based Language Teaching. Cambridge: Cambridge University Press.

Philips, S. (2003). Drama with children. Oxford: Oxford University Press.

Royka, J. (2002). Overcoming the fear of using drama in English language teaching. The Internet TESL Journal, 8(2). Retrieved from http://iteslj.org/Articles/Royka-Drama.html

Savignon, S. J. (1991). Communicative Language Teaching: State of the Art. TESOL Quarterly, 25(2), 261-277. Retrieved from http://links.jstor.org/sici?sici=00398322\%28199122\%2925\%3A2\%3C261\%3ACLTSOT\%3E2.0. CO\%3B2-R. https://doi.org/10.2307/3587463

Skehan, P. (1998). A Cognitive Approach to Language Learning. Oxford: Oxford University Press. Wessels, Ch. (1987). Drama (Resource Books for Teachers). Oxford: Oxford University Press.

Zyoud, M. (2010). Using Drama Activities and Techniques to Foster Teaching English as a Foreign Language: A Theoretical Perspective. Retrieved from www.quo.edu/english/conferences/.../pdf files/munther zyoud.pdf.

Wheeler, D. (2012). Golden Age Drama in Contemporary Spain: The Comedia on Page, Stage and Screen. Cardiff: University of Wales Press.

Willis, J. (1996). A Framework for Task-Based Learning. Essex: Longman Harlow. 